\title{
APPLICATION OF SOME LACTIC ACID BACTERIA STRAINS TO IMPROVE FERMENTATION AND AEROBIC STABILITY OF MAIZE SILAGE
}

\author{
Judit Peter Szucs, Agnes Suli, Timea Suli Zakar, Elizabet Berecz, Mate Pek \\ University of Szeged Faculty of Agriculture, Hódmezővásárhely, Hungary \\ H-6800 Hódmezővásárhely, Andrássy út 15., Hungary \\ szucsne.peter.judit@mgk.u-szeged.hu
}

\begin{abstract}
The object of the trial was to study the effect of some lactic acid bacteria strains on the fermentation and aerobic stability of whole plant maize silages.

The whole plant maize raw material was $32 \% \mathrm{DM}$, in soft cheddar stage of grain ripeness. It was ensiled in 4.2 litre capacity glass micro-size silos in 5 replicates /each treatment and stored on constant air conditioned room temperature $\left(22^{\circ} \mathrm{C}\right)$ during 95 days. The average packing density of raw material was $211 \mathrm{~kg} \mathrm{DM} / \mathrm{m}^{3}$. The applied treatments: 1. Untreated control maize, 2. Enterococcus faecium 100,000 CFU/g fresh maize (FM), 3. Lactobacillus plantarum 50,000 CFU/g FM + Enterococcus faecium 50,000 CFU/g FM, 4. Lactococcus lactis 100,000 CFU/g FM, 5. Lactobacillus plantarum 50,000 CFU/g FM + Lactococcus lactis 50,000 CFU/g FM, 6. Lactobacillus plantarum 100,000 CFU/g FM.

Aerobic stability study: Applied Honig (1990 system).

The main experiences are the following: Applied lactic acid bacteria strains improved the quality of fermentation of maize in general compare to untreated control one.

Lactic acid bacteria strains significantly stimulated lactic acid production and decreased propionic and butyric acid production. The origin of ammonia decreased also under influence of lactic acid bacteria strains in unaerobic conditions.

Enterococcus faecium and.Lactococcus lactis are not able to protect the maize silages against the aerobic deterioration with the applied dosage.

Lactobacillus plantarum itself produced the most favourable fermentation characteristics and protected the aerobic stability of silage the most effectively (during 4 day) compare to all other treated maize silages
\end{abstract}

Keywords: aerobic stability, fermentation, lactic acid bacteria strains, Lactobacillus plantarum,, maize silage

\section{INTRODUCTION}

Bacterial inoculants are expected to ensure a more efficient fementation phase as well as reduce the risk of aerobic deterioration when silages are exposed to air. Bacterial inoculants can improve fermentation characteristics first of all by speeding up the fall of $\mathrm{pH}$ and lowering ammonia levels because of reducing proteolysis into the silo. Various inoculant strains have been found to produce bacteriocins and other compounds that inhibit other bacteria and fungi improving their success (MUCK, 2013). Bacterial inoculants containing homofermentative lactic acid bacteria (LAB), in most of the cases Lactobacillus plantarum, secondly Enterococcus faecium, Lactococcus lactis are often added to silage because they very quickly produce large quantities of lactic acid, which lowers the $\mathrm{pH}$ of the silage (Li AND NisHINO, 2011; MARCIŇÁKOVÁ ET AL., 2008).

However, some bacterial inoculants often have no effect or can even make the aerobic stability of silages worse (LIN ET AL., 1992; PAHLOW AND HONIG, 1994; MUCK, 2013) because of the reduction of acetic acid (LINDGREN ET AL., 1990; MCDONALD ET AL., 1991; RUSER AND KLEIMAN, 2005) and also because yeasts metabolize lactic acid to produce alcohol (MUCK, 2013).

Recently, the aerobic stability of different silage crops has been markedly improved through inoculation with a heterolactic bacterium eg. Lactobacillus buchneri, Lactobacillus brevis. Acetic acid produce from heterofermentative LAB inhibits the 
proliferation of yeasts in silage (FILYA ET AL., 2002; RUSER AND KLEIMAN, 2005). Improvements in aerobic stability have been reported in corn silage (RANJIT AND KUNG, 2000; LI AND NisHINO, 2011, 2013).

Many additives have been developed to improve the ensiling process and nutritive value of silages At present biological additives containing lactic acid bacteria strains are preferred because they are non-toxic, non-corrosive to machinery, do not present environmental hazards and are regarded as natural products, and therefore bacterial inoculants have been very popular, over the last 20 years (DAVIES, 2010). Howewer their application cannot replace professional silage management.

\section{MATERIAL AND METHOD}

Experimental ensilage procedure

The applied treatments:

T1. Untreated control maize FM (fresh weight)

T2. Enterococcus faecium 100,000 CFU/g FM maize,

T3. Lactobacillus plantarum 50,000 CFU/g FM

+ Enterococcus faecium 50,000 CFU/g FM

T4. Lactococcus lactis 100,000 CFU/g FM

T5. Lactobacillus plantarum 50,000 CFU/g FM

+ Lactococcus lactis 50,000 CFU/g FM

T6. Lactobacillus plantarum 100,000 CFU/g FM maize

The inoculants were individually prepared for application by suspending the number of grams to be applied in distilled water and then evenly applying $2 \mathrm{ml}$ of suspension of bacterias / $\mathrm{kg}$ of forage (fresh weight). The same amount of distilled water was applied to the untreated maize as well. The maturity of whole plant maize raw material was in soft cheddar stage of grain ripeness and the dry matter content was $32 \%$. The harvested chopped maize was ensiled in 4.2 litre capacity air-tight sealed glass micro-size silos in 5 replicates /each treatment and stored on constant air-conditioned room temperature $\left(22{ }^{\circ} \mathrm{C}\right)$ during 95 days. The average packing density was $211 \mathrm{~kg} \mathrm{DM} / \mathrm{m}^{3}$.

\section{Chemical analysis}

$\mathrm{DM}, \mathrm{pH}$, lactic-, acetic-, propionic- and butyric acids, ammonia-N and ethanol content of silages were analysed according to the internationally recognised methods.

\section{Examination of aerobic stability}

Determination of aerobic stability of silages was monitored by System Völkenrode (Honig, 1990) principle.

It is based on monitoring temperature rise due to increased microbial activity of samples exposed to air.

\section{Procedure}

For the determination minimum $100 \mathrm{~g}$ samples are weight into a tins. Temperature sensors are placed into the centre of the samples and the whole unit is insulated with an outer layer of polystyrene on the sides and at bottom and top. The temperature is registered hourly by a computer program. From the values of each day a mean value is calculated. The room temperature is taken as the reference temperature about $22{ }^{\circ} \mathrm{C}$, and substrated from the silage temperatures. The measurement is continued for 7 days. 


\section{Evaluation}

The time a silage is supposed to be stable is given till the registration unit shows a temperature rise of $3{ }^{\circ} \mathrm{C}$ above ambient temperature.

\section{Statistical analysis}

Full statistical analyses was using an internationally recognised statistical procedure.

We processed data by means of IBM PC computer with the aid of Microsoft Excel program. As method of mathematical statistics, we used the method of comparison of calculated mean values and significance.

The raw material was analysed before ensilage, and the fermentation products of maize silages were analysed on $95^{\text {th }}$ day after ensiling.

\section{RESULTS AND DISCUSSION}

\section{Raw material}

The maturity of ensilaged silomaize was at the beginning of soft cheddar stage of grain ripeness. The chemical composition of these plant was similar to the standard average. DM content $32 \%$, which showed easy ensiling of raw material. There was no significant difference between all treatments, neither control nor treated samples, so the further differences in any other parameters were not originated from different DM content.

\section{Control silage}

After 95 days of storage $\mathrm{pH}$ of maize silage was 3.70. Significantly less $(\mathrm{P}=0.1 \%)$ lactic acid $(3.20 \%)$ more butyric acid $(0.08) \%$ was produced compare to the treated silages. The highest amount of $\mathrm{NH}_{3}(37.4 \mathrm{mg} \% \mathrm{DM})$ was detected in control silage compare to different strains of lactic acid bacteria treated silages which was significant in case of $\mathrm{T} 4$ $(\mathrm{P}=5 \%), \mathrm{T} 5$ and $\mathrm{T} 6$ silages $(\mathrm{P}=0.1 \%$ respectively) see Tables 1 and 2 .

The untreated control silage was stable until 3 and half day. The samples started to get warmer on $8^{\text {th }}$ hours and achieved $3{ }^{\circ} \mathrm{C}$ warmer temperature compare to ambient on $86^{\text {th }}$ hours (therefore lost stability). Pick temperature was $30^{\circ} \mathrm{C}$ on $136^{\text {th }}$ hours (Table 3).

\section{Enterococcus faecium treated silage,}

There were significant differences among $\mathrm{pH}$ and some fermentation products compare to the control silage:

There was higher $\mathrm{pH} 3.72(\mathrm{P}=5 \%)$ and lactic acid content $4.4 \%(\mathrm{P}=0.1 \%)$ less acetic acid $1.41 \%$ (non significant), butyric acid $0.01 \%(\mathrm{P}=1 \%)$ ethanol $1.8 \%(\mathrm{~ns})$ and ammonia $34 \mathrm{mg} \% \mathrm{DM}$ (ns).

The silage was stable less then 3 day only after opening the micro silos on aerobic condition. Getting warmer of silage started from $9^{\text {th }}$ hour, and suddenly rised the temperature with $3{ }^{\circ} \mathrm{C}$ higher than the ambient (which indicated the lost of stability) on $71^{\text {th }}$ hour (15 hours earlier than the control).

\section{Lactobacillus plantarum + Enterococcus faecium treated silage}

The $3.75 \mathrm{pH}$ and $5.11 \%$ lactic acid content of silage is significantly higher $(\mathrm{P}=0.1 \%)$ to the control silage. Less acetic- and butyric acid, ethanol and ammonia content are not significant compare to control one.

Aerob stability was relatively better than the control. 
The stability lasted until $86^{\text {th }}$ hour exposure to air but got worm 3 hours later ( $11^{\text {th }}$ hour) and the temperature of forages were rising slowly to pick $28^{\circ} \mathrm{C}$ until $174^{\text {th }}$ hour which was 38 hours later than the control.

\section{Lactococcus lactis treated silage}

$3.77 \mathrm{pH}$ and $5.12 \%$ lactic acid content are significantly higher $(\mathrm{P}=0.1 \%)$; the same acetic less butyric acid content and higher ethanol production are not significant, while the smaller $27 \mathrm{mg} \% \mathrm{DM}$ ammonia level is $\mathrm{P}=5 \%$ significant with control.

The deterioraiton of silage started in the $3^{\text {rd }}$ hour while its stability lasted in the $79^{\text {th }}$ hour $(7$ hours earlier than the control). Pick temperature $\left(33.2^{\circ} \mathrm{C}\right)$ was achieved in the $123^{\text {th }}$ hour (13 hours earlier than control).

\section{Lactobacillus plantarum + Lactococcus lactis treated silage}

Higher $\mathrm{pH}(3.77)$ and lactic acid production (5.40\%) and lower acetic acid production $(1.26 \%)$ were significantly different $(\mathrm{P}=0.1 \%)$ with control. Also differed significantly the lower butyric acid production $(0.006 \%)$ in $\mathrm{P}=1 \%$ level, and considerably high ethanol $(3 \%)$ in $\mathrm{P}=5 \%$ level. Ammonia production was only half $(56 \%)$ of control, which is significant on $\mathrm{P}=0.1 \%$ level.

Aerobic stability was kept only 89 hours (3 hours longer compare to control). Silage started to deteriorate from $11^{\text {th }}$ hours ( 3 hours later) and $37.9{ }^{\circ} \mathrm{C}$ pick temperature was achieved on the $115^{\text {th }}$ hours of aerobic stability test ( 21 hours later than the control silage).

\section{Lactobacillus plantarum treated silage}

Parameters of fermentation and their significance to the control are the following: higher $\mathrm{pH}$ (3.75) $\mathrm{P}=0.1 \%$; higher lactic acid (5.19 DM \%) $\mathrm{P}=0.1 \%$ lower acetic acid (1.37 DM $\%) \mathrm{P}=10 \%$; No butyric acid $\mathrm{P}=1 \%$, Half of ethanol content $(0.91 \mathrm{DM} \%) \mathrm{P}=5 \%$; Half of ammonia content ( $18.1 \mathrm{mg} \% \mathrm{DM}) \mathrm{P}=0.1 \%$ level of significance.

These fermentation characteristisc are the best among all other silages, not only in comparison with control, but also with the other lactobacillus bacterium treated silages as well.

The aerobic stability test showed the best results also:

Aerobic stability was kept until $95^{\text {th }}$ hour (4 day) ( 9 hours longer than control). Silage deterioration started on $12^{\text {th }}$ hour (4 hours later than the. control.

The pick temperature $25.7{ }^{\circ} \mathrm{C}$ was the lowest, and recorded on $190^{\text {th }}$ hour (54 hours later than control) which means low rising of temperature, slow deterioration of silage.

Table 1. Fermentation product of maize silages on DM basis

\begin{tabular}{|c|cc|cc|cc||}
\hline & \multicolumn{7}{|c||}{ Mean of treatments (n=5) } \\
Parameters & T1 & T2 & T3 & T4 & T5 & T6 \\
\hline Dry matter \% & 31,15 & 31,92 & 31,34 & 31,67 & 32,22 & 32,04 \\
\hline Lactic acid \% & 3,17 & 4,45 & 5,10 & 5,11 & 5,40 & 5,18 \\
Acetic acid \% & 1,46 & 1,42 & 1,38 & 1,47 & 1,26 & 1,37 \\
\hline Butyric acid \% & 0,08 & 0,03 & 0,06 & 0,04 & 0,01 & 0,00 \\
\hline Propionic acid \% & 0,24 & 0,08 & 0,18 & 0,05 & 0,08 & 0,13 \\
Ethanol \% & 1,89 & 1,78 & 2,35 & 2,44 & 3,01 & 0,92 \\
\hline Ammonia mg \% DM & 37,40 & 33,80 & 31,80 & 26,9 & 20,90 & 18,00 \\
\hline
\end{tabular}


Review on Agriculture and Rural Development 2018 vol. 7 (1-2) ISSN 2063-4803

Table 2. Statistical evaluation of some parameters of the fermentation on $95^{\text {th }}$ day

\begin{tabular}{|c|c|c|c|c|c|c|c|c|c|c|c|c|c|c|c|c|c|}
\hline \multirow{3}{*}{\multicolumn{2}{|c|}{ Param eters }} & \multirow{3}{*}{$\mathbf{n}$} & \multicolumn{12}{|c|}{ Treatment } & \multirow{3}{*}{$t^{*}$} & \multirow[b]{2}{*}{ Level of signif. } & \multirow{3}{*}{$\begin{array}{c}\text { Diff. of signif. } \\
(\mathrm{p} \%)\end{array}$} \\
\hline & & & \multicolumn{2}{|c|}{$\begin{array}{c}\text { T1 } \\
\text { (Control) }\end{array}$} & \multicolumn{2}{|c|}{ T2 } & \multicolumn{2}{|c|}{ T3 } & \multicolumn{2}{|c|}{ T4 } & \multicolumn{2}{|c|}{ T5 } & \multicolumn{2}{|c|}{ T6 } & & & \\
\hline & & & Mean & $s$ & Mean & $s$ & Mean & s & Mean & $s$ & Mean & s & Mean & $s$ & & & \\
\hline pH & & 5 & 3,69 & 0,01 & 3,72 & 0,02 & 3,75 & 0,01 & 3,77 & 0,01 & 3,77 & 0,02 & 3,75 & 0,01 & $\begin{array}{l}t_{1-2}=2,42 \\
t_{1-3}=5,27 \\
t_{1-4}=7,65 \\
t_{1-5}=8,25 \\
t_{1-6}=5,84\end{array}$ & $\begin{array}{l}0,1 \% \\
0,1 \% \\
0,1 \% \\
0,1 \%\end{array}$ & $\begin{array}{l}0,040 \\
0,037 \\
0,037 \\
0,037\end{array}$ \\
\hline Lactic acid & DM\% & 5 & 3,17 & 0,36 & 4,44 & 0,33 & 5,11 & 0,55 & 5,12 & 0,45 & 5,40 & 0,47 & 5,19 & 0,45 & $\begin{array}{l}t_{1-2}=4,61 \\
t_{1-3}=6,63 \\
t_{1}-4=7,06 \\
t_{1-5}=8,07 \\
t_{1-\sigma}=7,30\end{array}$ & $\begin{array}{l}0,1 \% \\
0,1 \% \\
0,1 \% \\
0,1 \% \\
0,1 \% \\
\end{array}$ & $\begin{array}{l}1,036 \\
1,036 \\
1,036 \\
1,036 \\
1,036\end{array}$ \\
\hline Acetic acid & DM\% & 5 & 1,46 & 0,16 & 1,41 & 0,04 & 1,38 & 0,06 & 1,47 & 0,05 & 1,26 & 0,02 & 1,37 & 0,07 & $\begin{array}{l}t_{1-2}=0,81 \\
t_{1-3}=1,42 \\
t_{1-4}=0,19 \\
t_{1-5}=3,81 \\
t_{1-\sigma}=1,73\end{array}$ & $\begin{array}{c}\text { ns* }^{* *} \\
\text { ns } \\
\text { ns } \\
0,1 \% \\
10 \%\end{array}$ & $\begin{array}{l}- \\
- \\
- \\
0,195 \\
0,089\end{array}$ \\
\hline Butyric acid & DM\% & 5 & 0,077 & 0,03 & 0,012 & 0,01 & 0,056 & 0,07 & 0,044 & 0,04 & 0,006 & 0,01 & 0,001 & 0,000 & $\begin{array}{l}t_{1-2}=3,19 \\
t_{1}-3=1,00 \\
t_{1-4}=1,61 \\
t_{1-5}=3,29 \\
t_{1-\sigma}=3,72\end{array}$ & $\begin{array}{c}1 \% \\
\text { ns } \\
\text { ns } \\
1 \% \\
1 \% \\
\end{array}$ & $\begin{array}{l}0,057 \\
- \\
0,061 \\
0,057 \\
\end{array}$ \\
\hline E thanol & DM\% & 5 & 1,89 & 0,49 & 1,78 & 0,77 & 2,35 & 0,19 & 2,44 & 0,33 & 3,01 & 0,75 & 0,91 & 1,29 & $\begin{array}{l}t_{1-2}=0,23 \\
t_{1-3}=0,92 \\
t_{1-4}=1,15 \\
t_{1-5}=2,37 \\
t_{1-\sigma}=2,08\end{array}$ & $\begin{array}{l}\text { ns } \\
\text { ns } \\
\text { ns } \\
5 \% \\
5 \%\end{array}$ & $\begin{array}{l}- \\
- \\
- \\
0,971 \\
0,971\end{array}$ \\
\hline Ammonia & $\mathrm{mg} \%$ & 5 & 37,4 & 4,74 & 34,02 & 5,85 & 31,78 & 1,46 & 26,94 & 3,26 & 20,9 & 5,00 & 18,10 & 10,95 & $\begin{array}{l}\mathrm{t}_{1-2}=0,89 \\
\mathrm{t}_{1-3}=1,38 \\
\mathrm{t}_{1-4}=2,72 \\
\mathrm{t}_{1-5}=4,29 \\
\mathrm{t}_{1-6}=5,01\end{array}$ & $\begin{array}{c}\text { ns } \\
\text { ns } \\
5 \% \\
0,1 \% \\
0,1 \% \\
\end{array}$ & $\begin{array}{l}- \\
7,945 \\
14,464 \\
14,464\end{array}$ \\
\hline
\end{tabular}

*Critical level of „t”: $\mathrm{P}_{10 \%}: 1,71 ; \mathrm{P}_{5 \%}: 2,06 ; \mathrm{P}_{1 \%}: 2,8 ; \mathrm{P}_{0,1 \%}: 3,75$

** ns : non significant

Table 3. Summary of aerobic stability test in fermentation study

\begin{tabular}{|c|c|c|c|c|c|c|}
\hline \multirow{2}{*}{ Treatment } & Get warm & $\begin{array}{c}\text { Finish of aerob } \\
\text { stability }\end{array}$ & \multicolumn{2}{|c|}{$\begin{array}{c}\mathbf{1}^{\text {st }} \text { Pick } \\
\text { temperature }\end{array}$} & \multicolumn{2}{|c|}{$\begin{array}{c}\mathbf{2}^{\text {nd }} \text { Pick } \\
\text { temperature }\end{array}$} \\
\cline { 2 - 7 } & hour & hour & hour & ${ }^{\circ} \mathbf{C}$ & hour & ${ }^{\circ} \mathbf{C}$ \\
\hline T1 & 8 & 86 & 136 & 29.9 & -- & -- \\
\hline T2 & 9 & 71 & 149 & 28.5 & -- & -- \\
\hline T3 & 11 & 86 & 174 & 28.0 & -- & -- \\
\hline T4 & 3 & 79 & 123 & 33.2 & -- & -- \\
\hline T5 & 11 & 89 & 95 & 37.9 & 182 & 38.1 \\
\hline T6 & 12 & 95 & 190 & 25.7 & -- & -- \\
\hline
\end{tabular}

\section{CONCLUSIONS}

- Applied lactic acid bacteria strains improved the quality of fermentation of maize silages in general compare to untreated control one.

- Lactic acid bacteria strains significantly stimulated lactic acid production and decreased propionic and butyric acid production.

- The origin of ammonia decreased also under influence of lactic acid bacteria strains in unaerobic conditions.

- Enterococcus faecium and Lactococcus lactis itself are not able to improve the protection of the aerobic stability of maize silages with the applied dosage.

- Lactobacillus plantarum applied itself produced the most favourable fermentation characteristics of silage and protected the most effectively the aerobic stability of maize silage (during 4 day) compare to all other lactic acid bacteria strains. 


\section{REFERENCES}

DAVIES, D.R (2010): Silage inoculants - where next? In: V. Jambor, S. Jamborova, B. Vosynkova, P. Prochacka, D. Vosynkova, D. Kumprechtova (Eds.): Proceedings of the 14th International Symposium Forage Conservation. Mendel University, Brno, Czech Republic. Pp. 32-39.

Filya, I., Karabulut, A., SuCu, E. (2002): The effect of Lactobacillus plantarum and Lactobacillus buchneri on the fermentatin, aerobic stability and ruminal degradability of corn silage in warm climate in Proceedings of the 13th International Silage Conference LI, Y., NisHINO, N. (2011): Monitoring the bacterial community of maize silage stored in a bunker silo inoculated with Enterococcus faecium, Lactobacillus plantarum and Lactobacillus buchneri. J Appl. Microbiol. 110: 1561-1570.

LI, Y., NisHINO, N. (2013) Effects of ensiling fermentation and aerobic deterioration on the bacterial community in italian regrass, ginea grass, and whole-crop maize silages stored at high moisture content Asian-Australasian Journal of Animal Sciences (AJAS) 26, 9, pp. 1304-1312.

Lin, C., Bolsen, K.K., Brent, B.E., Fung, D.Y. (1992): Epiphytic lactic acid bacteria succession during the pre-ensiling and ensiling periods of alfalfa and maize. J Appl Bacteriol. 173: 375-387.

Lindgren, S.E., AXELsson, L.T., MCFeEters, R.F. (1990): Anaerobic L-lactate degradation by Lactobacillus plantarum. FEMS Microbiol Lett. 66: 209-213.

MarciňÁková, M., Laukova, A., Simonova, M., Strompfova, V., KoreneKova, B., NAD̆, P. (2008): Probiotic properties of Enterococcus faecium EF9296 strain isolated from silage. Czech Journal of Animal Science 53: 336-345.

McDonald, P., Henderson, A.R., Heron, S.J. (1991): The biochemistry of silage. Chalcombe Publications; Lincoln, UK

MuCK, R.E. (2013): Recent advances in silage Microbiology Agricultural and Food Science 22: 3-15.

PAHLOW, G., HoniG, H. (1994): The role of microbial additives in the aerobic stability of silage. Proceedings of the 15th General Meeting of EGF, the Netherlands. Pp. 149-152.

RANJIT, N.K., KUNG, L. (2000): The effect of Lactobacillus buchneri, Lactobacillus plantarum, or a chemical preservative on the fermentation and aerobic stability of corn silage. Journal of Dairy Science 83(3): 526-535.

Ruser, B., KLEIMAN, J. (2005): The effect of acetic acid on the aerobic stability of silages and on intake. Proc. XIVth International Silage Conference. Belfast, Northern Ireland. 231 p. 